\title{
Turbidite provenance in the Lower Palaeozoic Manx Group, Isle of Man: implications for the tectonic setting of Eastern Avalonia
}

\author{
D. J. BURNETT ${ }^{1} \&$ D. G. QUIRK ${ }^{2}$ \\ ${ }^{1}$ Geology, Oxford Brookes University, Gipsy Lane, Oxford OX3 OBP, UK (e-mail: dave_burnett73@hotmail.com) \\ ${ }^{2}$ Amerada Hess Ltd., Grosvenor Place, London SWIX 7HY, UK (e-mail: Dave.Quirk@Hess.com)
}

\begin{abstract}
The provenance of turbidites from the predominantly Arenig-aged Manx Group has been constrained using petrographical and geochemical techniques. Petrographical analysis of sandstones reveals that mono- and poly-crystalline quartz grains of cratonic origin are dominant. Major, trace and rare earth element concentrations in both sandstones and mudstones complement the petrographical data indicating that the source of the sediments consisted of quartzose basement and mature sedimentary rocks. There is little evidence of a juvenile volcanic input but a minor palaeovolcanic component of active continental margin affinity is present. There are indications of a more immature character in the oldest units but, on the whole, geochemical data from the Manx Group suggest an overall passive margin setting. These results suggest that Eastern Avalonia was attached to Gondwana during deposition of the Manx Group and that Iapetus oceanic crust did not subduct beneath the region before the end of the Arenig.
\end{abstract}

Keywords: Manx Group, Avalonia, Iapetus, provenance, geochemistry.

It is now well established that during much of the Early Palaeozoic Era the Iapetus Ocean separated the microcontinent of Eastern Avalonia to the south from the northern continent of Laurentia. According to Nance \& Murphy (1994), Eastern Avalonia developed on an active continental margin around the West African part of Gondwana during the Neoproterozoic. After the margin became inactive (c. $580 \mathrm{Ma})$, stable platform conditions persisted through the Cambrian until two tectonic events occurred some time in the early Ordovician: (1) subduction of Iapetus oceanic crust beneath Eastern Avalonia and (2) rifting of Eastern Avalonia from Gondwana (e.g. Prigmore et al. 1997). However, there is considerable uncertainty over the timing of these events, particularly as to when an active margin became fully established along the northern edge of Eastern Avalonia (e.g. Kokelaar 1988; Barnes \& Stone 1999).

The Lower Palaeozoic Manx Group makes up approximately three-quarters of the exposed strata on the Isle of Man (Fig. 1a). It comprises deep marine turbidites with subordinate debrites deposited on the northern margin of Eastern Avalonia during the Tremadoc and Arenig (Woodcock et al. 1999a; Molyneux pers. comm.; Fig. 1b). The Manx Group therefore holds potentially important information on the tectonic evolution of Eastern Avalonia. These exposures are also crucial in linking contemporaneous deposits in NW England and SE Ireland.

In this study the provenance of the Manx Group is determined using petrographical as well as major, trace and rare earth element data. Such data allow inferences to be made on the source of the sediments and their depositional setting.

\section{Manx Group stratigraphy}

Due to the presence of major faults (Quirk et al. 1999) and only limited palaeontological control (Molyneux 1999), the stratigraphy of the Manx Group cannot be constrained with great confidence. However, recent work by Woodcock et al. (1999b) and Quirk \& Burnett (1999) has defined litho- stratigraphic units which have been further refined using chemostratigraphy by Burnett (1999) (Fig. 1a). Based mostly on their chemical compositions, the lithostratigraphic units have been grouped in this paper into three different types (Lonan-, Agneash- and Injebreck-types) (Fig. 2). These are primarily based upon characteristics initially defined by Barnes et al. (1999) and expanded on by Burnett (1999). The Lonan-type group (consisting of the Lonan, Santon and $\mathrm{Ny}$ Garvain Formations) is late Tremadoc-early Arenig in age. The Agneash-type group (Port Erin, Mull Hill, Creg Agneash and Maughold Formations) stratigraphically overlies the Lonan-type group it is therefore interpreted to be of an early-mid Arenig age. The Injebreck-type group is mostly mid-late Arenig although recent analysis of acritarch assemblages suggests that the Glen Dhoo and Glion Cam units were deposited in the Tremadoc (Molyneux pers. comm.) and are separated by a major fault from the rest of the Injebrecktype units (the Barrule, Injebreck, Glen Rushen and Creggan Mooar Formations). The relationship of the 'early' Injebreck-type units to the Lonan-type is problematic.

The Glen Dhoo and Glion Cam units are shown at the base of the succession in Figure 2 although their stratigraphic position relative to the rest of the Manx Group is uncertain. Despite limited outcrop, the Glen Dhoo unit contains mostly mudstone in its NW part but is dominated by quartz wackes to the SE while the Glion Cam unit is greywacke-prone. The Manx Group is dominated by quartz wackes in the Lonan, Santon and Ny Garvain Formations, followed by quartz arenites in the Creg Agneash and Mull Hill Formations (Fig. 2). The overlying Maughold Formation also contains quartz arenites but becomes increasingly mudstone-dominated upwards and younger units such as the Barrule, Injebreck, Creggan Mooar and Glen Rushen Formations are primarily composed of mudstone with occasional sandstone packages. Two minor occurrences of andesite, tuff and agglomerate (Simpson 1963), termed the Peel volcanics and Ballaquane volcanics, are present in the Manx Group although their stratigraphic position is uncertain as they lie close to a major fault (Fig. 1a). 


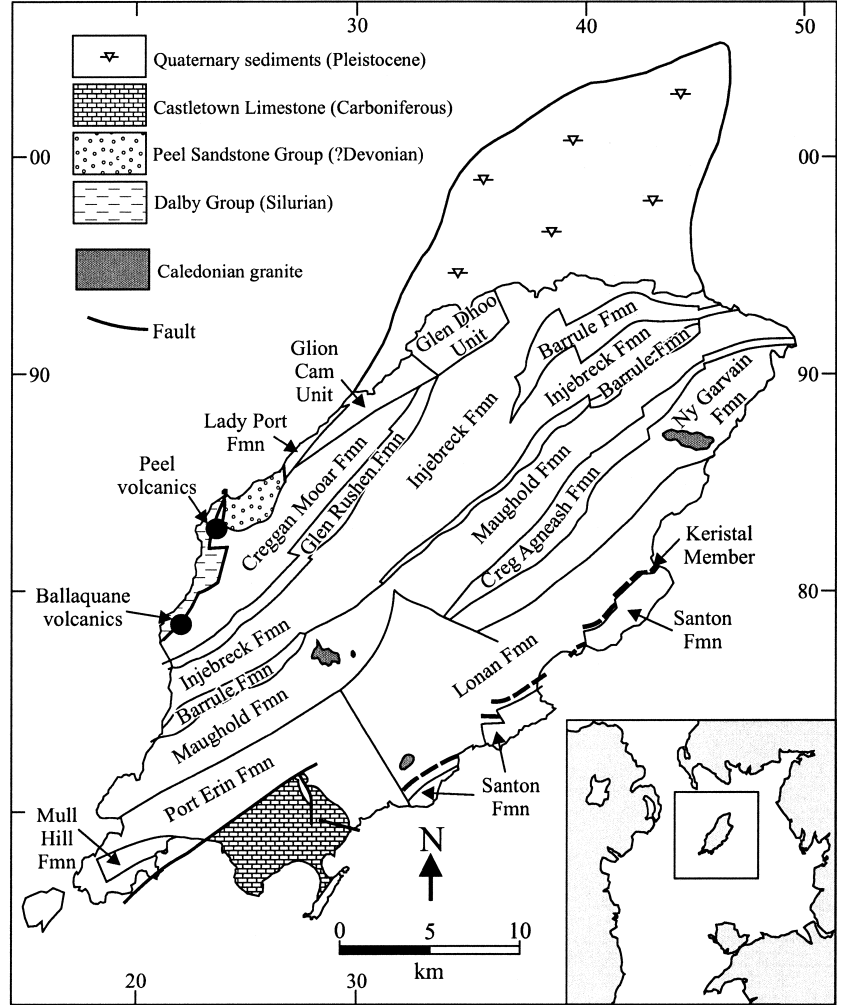

(a)

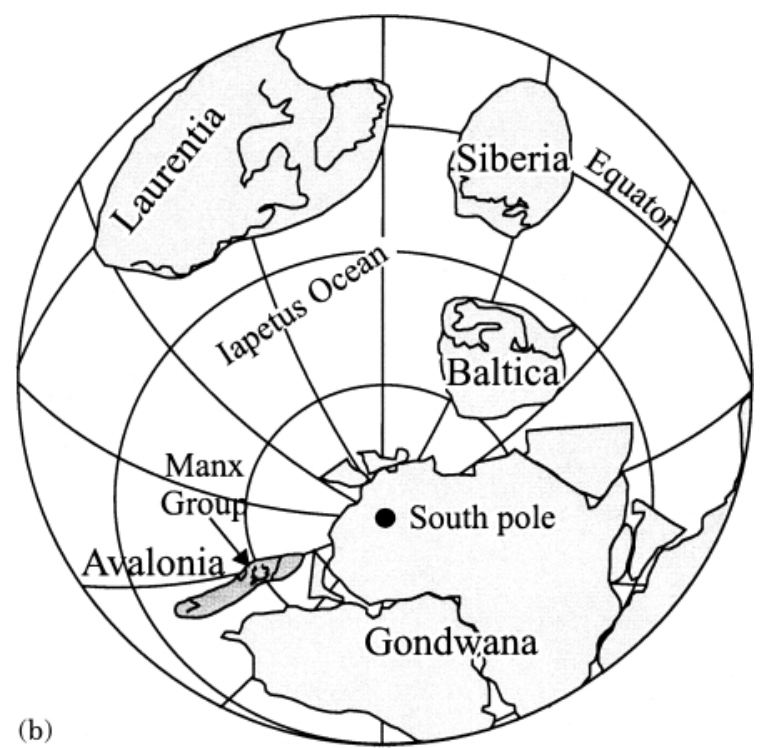

Fig. 1. (a) Simplified map of Manx Group lithostratigraphic units. Named formations with no ornament are part of the Manx Group. (b) Palaeogeographic reconstruction for the Arenig (480 Ma), showing the position of the Manx Group region relative to Eastern Avalonia, Gondwana and the Iapetus Ocean (after Cocks 2000).

\section{Petrography}

The main assumption behind sandstone provenance studies is that different tectonic settings contain characteristic rock types which, when eroded, produce sandstones with specific compositional ranges (Dickinson 1985). The analysis of sandstones with known provenance has been used to define these ranges from which the provenance of other samples can be deduced.

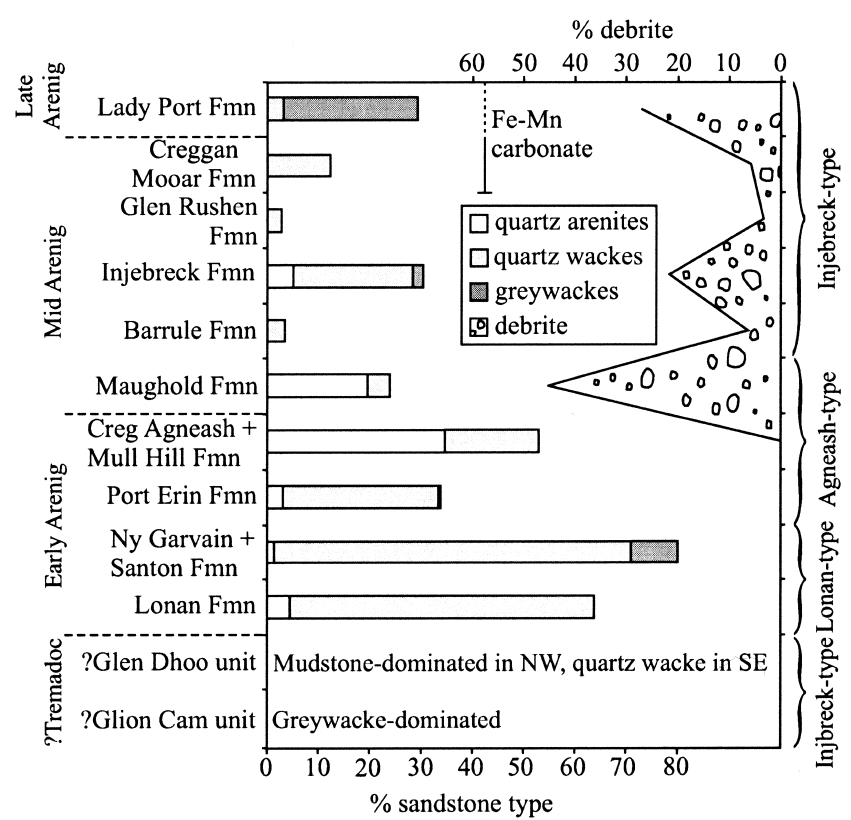

Fig. 2. Manx Group stratigraphy with general sedimentological changes. Insufficient field data have been collected to display accurately the sedimentological characteristics of the Glen Dhoo and Glion Cam units.

Sixty-one sandstone samples from the Manx Group were collected, wherever possible from the planar-laminated portions of the least weathered turbidites. Most stratigraphic units have at least three point-counted samples from them except for the Glen Dhoo unit (two samples), and the Lady Port and Creggan Mooar Formations (one sample each). The mudstone-dominated Barrule and Glen Rushen Formations have no petrographical samples due to a lack of suitable sandstones. The location of petrographical samples is given in Table 1.

300 points were counted per thin section, excluding matrix (grains $<0.03 \mathrm{~mm}$ ), using the Gazzi-Dickinson method (see Ingersoll et al. 1984). This involves counting grains greater than $0.0625 \mathrm{~mm}$ as individual phases even where they form part of a lithic fragment. Only when the cross-hairs of the microscope fall on grains within a lithic fragment which are less than $0.0625 \mathrm{~mm}$ is the fragment counted as a lithic grain. The purpose of this is to eliminate apparent variations in the composition of samples resulting only from differences in grain size.

Although care was taken to avoid alteration due to weathering by collecting only the freshest samples, high matrix contents in some Manx Group samples ( $>25 \%$ ) suggests that diagenetic alteration of some grains to matrix may have occurred. In several studies (e.g. Dickinson et al. 1983), samples with greater than $25 \%$ matrix are disregarded in order to prevent mistaken provenance assignment due to diagenetic changes to the modal composition. Although 36 out of the 61 Manx Group samples fall within this matrix limit, in order to provide data from as many stratigraphic units as possible, 25 samples above this limit have been included.

\section{Qualitative petrography}

The analysed sandstones are very fine- to fine-grained or occasionally medium-grained. In general they are poorly 
Table 1. Framework grain mode parameters of sandstones from the Manx Group

\begin{tabular}{|c|c|c|c|c|c|c|c|c|c|}
\hline \multirow[t]{2}{*}{ Lithostrat. unit } & \multirow[t]{2}{*}{ Sample } & \multirow[t]{2}{*}{ SC grid reference } & \multicolumn{3}{|c|}{$\mathrm{QFL} \%$} & \multicolumn{3}{|c|}{ QmFLt $\%$} & \multirow[t]{2}{*}{ Matrix $\%$} \\
\hline & & & Q & $\mathrm{F}$ & $\mathrm{L}$ & Qm & $\mathrm{F}$ & $\mathrm{Lt}$ & \\
\hline Creggan Mooar & C62 & 21137758 & 78.0 & 22.0 & 0.0 & 78.0 & 22.0 & 0.0 & 46.0 \\
\hline \multirow[t]{6}{*}{ Injebreck } & $\mathrm{C} 15$ & 41769252 & 98.3 & 1.7 & 0.0 & 98.3 & 1.7 & 0.0 & 24.2 \\
\hline & $\mathrm{C} 17$ & 42029113 & 99.0 & 1.0 & 0.0 & 99.0 & 1.0 & 0.0 & 30.6 \\
\hline & $\mathrm{C} 33$ & 38318798 & 100.0 & 0.0 & 0.0 & 100.0 & 0.0 & 0.0 & 16.9 \\
\hline & C52 & 21577451 & 97.3 & 2.7 & 0.0 & 97.3 & 2.7 & 0.0 & 26.9 \\
\hline & DJB4 & 37669131 & 100.0 & 0.0 & 0.0 & 100.0 & 0.0 & 0.0 & 42.3 \\
\hline & DJB6 & 42169152 & 99.3 & 0.7 & 0.0 & 99.3 & 0.7 & 0.0 & 37.4 \\
\hline \multirow[t]{6}{*}{ Maughold } & A11a & 38668539 & 100.0 & 0.0 & 0.0 & 100.0 & 0.0 & 0.0 & 9.0 \\
\hline & $\mathrm{C} 10$ & 18436993 & 97.0 & 3.0 & 0.0 & 96.7 & 3.0 & 0.3 & 2.9 \\
\hline & $\mathrm{C} 12 \mathrm{a}$ & 20657161 & 94.3 & 5.7 & 0.0 & 94.3 & 5.7 & 0.0 & 13.0 \\
\hline & C13 & 20607197 & 100.0 & 0.0 & 0.0 & 100.0 & 0.0 & 0.0 & 17.5 \\
\hline & $\mathrm{C} 36$ & 40848725 & 100.0 & 0.0 & 0.0 & 100.0 & 0.0 & 0.0 & 7.7 \\
\hline & C46 & 21427325 & 99.3 & 0.7 & 0.0 & 99.3 & 0.7 & 0.0 & 3.8 \\
\hline \multirow[t]{10}{*}{ Creg Agneash } & A13 & 42318615 & 98.7 & 1.3 & 0.0 & 98.7 & 1.3 & 0.0 & 3.2 \\
\hline & A 15 & 44968944 & 100.0 & 0.0 & 0.0 & 100.0 & 0.0 & 0.0 & 2.6 \\
\hline & A16 & 44968944 & 100.0 & 0.0 & 0.0 & 99.3 & 0.0 & 0.7 & 0.3 \\
\hline & $\mathrm{C} 21$ & 49639128 & 99.0 & 1.0 & 0.0 & 99.0 & 1.0 & 0.0 & 9.4 \\
\hline & $\mathrm{C} 22$ & 49769159 & 100.0 & 0.0 & 0.0 & 100.0 & 0.0 & 0.0 & 10.7 \\
\hline & C38 & 41778673 & 99.0 & 1.0 & 0.0 & 99.0 & 1.0 & 0.0 & 13.3 \\
\hline & DJB7 & 49769159 & 99.3 & 0.7 & 0.0 & 99.3 & 0.7 & 0.0 & 6.3 \\
\hline & HM3 & 47649113 & 97.7 & 2.3 & 0.0 & 97.7 & 2.3 & 0.0 & 7.4 \\
\hline & P16a & 39028403 & 100.0 & 0.0 & 0.0 & 99.7 & 0.0 & 0.3 & 14.0 \\
\hline & P17a & 39028403 & 99.3 & 0.7 & 0.0 & 99.0 & 0.7 & 0.3 & 2.6 \\
\hline \multirow[t]{3}{*}{ Mull Hill } & C44 & 21516850 & 98.3 & 1.7 & 0.0 & 97.7 & 1.7 & 0.7 & 4.5 \\
\hline & C45 & 21516850 & 93.1 & 6.9 & 0.0 & 92.8 & 6.9 & 0.3 & 36.8 \\
\hline & HM1 & 19036740 & 97.7 & 2.3 & 0.0 & 97.3 & 2.3 & 0.3 & 25.6 \\
\hline \multirow[t]{4}{*}{ Port Erin } & C11 & 19426962 & 100.0 & 0.0 & 0.0 & 100.0 & 0.0 & 0.0 & 6.0 \\
\hline & $\mathrm{C} 41$ & 29606722 & 90.0 & 10.0 & 0.0 & 89.0 & 10.0 & 1.0 & 24.1 \\
\hline & $\mathrm{C} 42$ & 28476545 & 88.3 & 11.7 & 0.0 & 85.0 & 11.7 & 3.3 & 55.3 \\
\hline & DJB8 & 28476545 & 92.0 & 8.0 & 0.0 & 91.7 & 8.0 & 0.3 & 45.0 \\
\hline & DJB2 & 48058901 & 88.6 & 11.4 & 0.0 & 88.6 & 11.4 & 0.0 & 20.6 \\
\hline & HM2 & 48568945 & 97.7 & 2.3 & 0.0 & 97.7 & 2.3 & 0.0 & 20.8 \\
\hline \multirow[t]{13}{*}{ Santon } & A1 & 43998112 & 88.3 & 11.7 & 0.0 & 85.0 & 11.7 & 3.3 & 48.4 \\
\hline & A17a & 37257354 & 85.9 & 14.1 & 0.0 & 84.0 & 14.1 & 2.0 & 30.6 \\
\hline & $\mathrm{A} 17 \mathrm{~b}$ & 37257354 & 87.1 & 12.3 & 0.7 & 80.1 & 12.3 & 7.6 & 35.6 \\
\hline & A18a & 38747440 & 89.3 & 10.3 & 0.3 & 87.3 & 10.3 & 2.3 & 35.5 \\
\hline & B3 & 42047827 & 99.7 & 0.3 & 0.0 & 93.3 & 0.3 & 6.3 & 4.4 \\
\hline & $\mathrm{C} 18$ & 37957510 & 96.7 & 3.3 & 0.0 & 96.0 & 3.3 & 0.7 & 21.9 \\
\hline & $\mathrm{C} 40$ & 38317499 & 84.7 & 15.3 & 0.0 & 84.3 & 15.3 & 0.3 & 40.9 \\
\hline & C48 & 36997350 & 73.7 & 26.3 & 0.0 & 73.3 & 26.3 & 0.3 & 43.2 \\
\hline & $\mathrm{C} 50$ & 36737333 & 88.7 & 11.3 & 0.0 & 87.7 & 11.3 & 1.0 & 31.8 \\
\hline & C51 & 36667329 & 81.7 & 18.3 & 0.0 & 81.4 & 18.3 & 0.3 & 41.7 \\
\hline & Pla & 38657445 & 98.0 & 2.0 & 0.0 & 97.3 & 2.0 & 0.7 & 15.8 \\
\hline & Plc & 38657445 & 97.0 & 3.0 & 0.0 & 96.3 & 3.0 & 0.7 & 18.9 \\
\hline & $\mathrm{P} 4 \mathrm{a}$ & 41807805 & 93.0 & 7.0 & 0.0 & 93.0 & 7.0 & 0.0 & 24.2 \\
\hline Keristal & $\mathrm{C} 19$ & 99907727 & 99.0 & 1.0 & 0.0 & 99.0 & 1.0 & 0.0 & 23.5 \\
\hline & $\mathrm{C} 43$ & 30626975 & 99.3 & 0.7 & 0.0 & 99.3 & 0.7 & 0.0 & 8.0 \\
\hline & C47 & 35407300 & 95.0 & 4.7 & 0.3 & 95.0 & 4.7 & 0.3 & 18.3 \\
\hline & HM4 & 43658128 & 98.3 & 1.7 & 0.0 & 98.0 & 1.7 & 0.3 & 14.3 \\
\hline Lonan & P19 & 43458150 & 87.0 & 13.0 & 0.0 & 86.7 & 13.0 & 0.3 & 0.0 \\
\hline & Pla & 38657445 & 98.0 & 2.0 & 0.0 & 97.3 & 2.0 & 0.7 & 16.2 \\
\hline & Plc & 38657445 & 97.0 & 3.0 & 0.0 & 96.3 & 3.0 & 0.7 & 18.9 \\
\hline Glen Dhoo & $\mathrm{C} 2$ & 34759018 & 98.7 & 1.3 & 0.0 & 98.7 & 1.3 & 0.0 & 37.9 \\
\hline & $\mathrm{C} 71$ & 34409150 & 76.3 & 23.7 & 0.0 & 76.3 & 23.7 & 0.0 & 26.6 \\
\hline Glion Cam & $\mathrm{C} 59$ & 29628867 & 80.2 & 19.8 & 0.0 & 80.2 & 19.8 & 0.0 & 49.8 \\
\hline & C60 & 29438821 & 68.9 & 31.1 & 0.0 & 68.6 & 31.1 & 0.3 & 40.6 \\
\hline & P15a & 29098758 & 88.0 & 12.0 & 0.0 & 84.7 & 12.0 & 3.3 & 62.6 \\
\hline
\end{tabular}



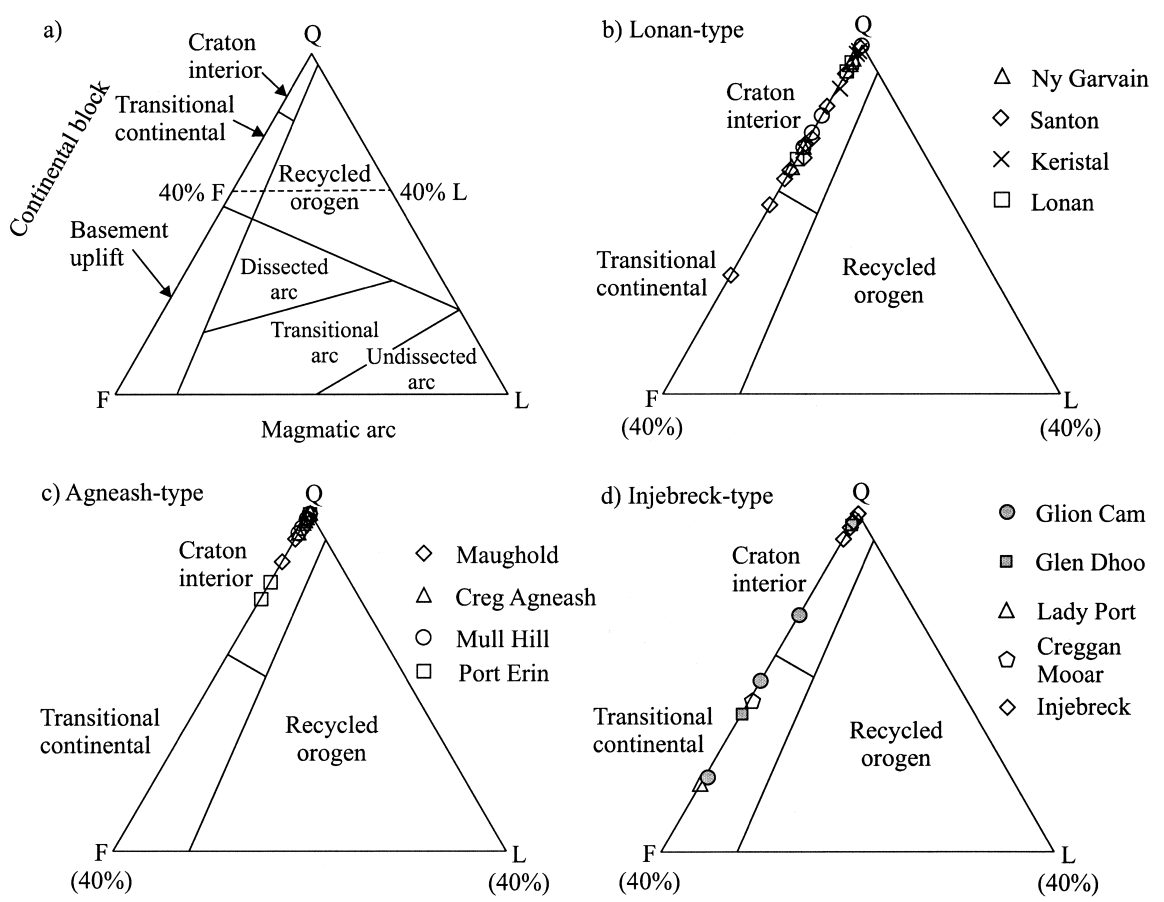

Fig. 3. QFL plots. (a) Provenance fields of Dickinson et al. (1983); (b-d) Manx Group sandstone samples of

(b) Lonan-type, (c) Agneash-type and (d) Injebreck-type. In order to reflect their uncertain relationship with the rest of the Manx Group, the Glen Dhoo and Glion Cam unit samples are shown in grey.

sorted, with constituent grains commonly angular to subangular with low to moderate estimated sphericity although the most quartzose lithologies often consist entirely of sutured and/or polygonized quartz. Well-rounded grains have also been observed but these are rare.

Quartz. Quartz, and specifically monocrystalline quartz, is the major detrital phase in the Manx Group. Common quartz is dominant in all samples although vein-derived quartz is also present. Inclusions of chlorite, muscovite and needles of rutile have been observed. The majority of quartz grains $(69 \%)$ are strained. Overgrowths are not obvious.

Feldspar. After quartz, feldspar is the most abundant mineral phase, typically accounting for $4 \%$ of the grains. Of these, alkali feldspar, particularly orthoclase, is the most common. Orthoclase grains are usually untwinned but simple twinning is observed in some cases. Plagioclase is the second most abundant feldspar, with compositions in the albite-andesine range where this can be determined optically. A small minority of feldspar grains exhibit plate- and lath-like morphologies and these are usually plagioclase.

Lithic fragments. The Manx Group contains detrital lithic fragments of metamorphic, sedimentary and igneous origin, in order of decreasing abundance. Compositionally, the most abundant types of lithic fragment are polycrystalline quartz varieties. These are primarily metamorphic fragments and chert. The metamorphic grains are composed of $100 \%$ quartz except for a small number with schistose textures that contain aligned mica. Other polycrystalline quartzose fragments include quartz arenite and occasional grains of rhyolite. A small proportion of quartzose lithic fragments could not be positively identified and remain unclassified largely due to the difficulty in distinguishing between chert and rhyolite. Other fragments of igneous rock occur rarely and include granite (sometimes with granophyric texture), volcanic acidintermediate clasts with aphanitic texture and rounded fragments of silicified ash.
Phyllosilicates. Phyllosilicates are generally confined to the matrix. However, elongate laths and small plates of white mica and chlorite are present in very low abundance.

Heavy minerals. A limited range of heavy minerals has been observed in thin-section. The most common are zircons, most of which are well-rounded. The second most abundant are well-rounded, green/brown tourmalines and rutiles, observed in two samples.

Matrix. The mean matrix content for sandstones from the Manx Group is $21 \%$. Matrix is generally composed of finely comminuted and altered lithic and feldspathic fragments, quartz, chlorite, white mica, opaques and material too fine to be identified. It is uncertain as to how much of the matrix is primary and how much has been produced by the alteration of feldspars and lithic fragments. However, some of the matrix is clearly 'pseudomatrix' as defined by Dickinson (1970) representing altered detrital framework grains.

\section{Quantitative petrography}

Quartz, feldspar and lithic fragment contents of Manx Group samples have been plotted on a QFL diagram with the provenance fields of Dickinson et al. (1983) superimposed (Fig. 3). This figure illustrates the quartzose, mineralogically mature nature of the Manx Group with the majority (88\%) of the Manx Group clustering comfortably within the craton interior field and only seven samples plotting outside. The Santon Formation and Glion Cam unit contain the most immature sandstones with samples plotting in the transitional area between craton interior and basement uplift provenances. Samples from the Creggan Mooar and Lady Port Formations and the Glen Dhoo unit also plot in this zone although the smaller sample sets for these intervals make their significance more questionable.

The majority of samples occupy the same provenance fields on Dickinson \& Suczek's (1979) QmFLt (monocrystalline quartz-feldspar-total lithic fragments) plot, reflecting the 
low proportion of polycrystalline lithic fragments (Burnett 1999).

Seven petrographical samples from the Manx Group were analysed by Moore (1992). These were more heterogeneous than those in this study with samples split between the craton interior field and the quartz-dominated part of the recycled orogen field on the QFL diagram. Morris et al. (1999) reported six coarse-grained sandstone samples from Purt Veg (part of the Santon Formation) as plotting in the recycled orogen field of Dickinson et al. (1983). The probable reason for the discrepancy between the results of Morris et al. (1999) and those of this study is the difference in grain-size. Although the Gazzi-Dickinson point-counting technique significantly reduces the grain-size effect, it cannot compensate for the increased proportion of lithic fragments within sediments at the coarser end of the spectrum, especially where these fragments are of silt-grade or finer and therefore included within the lithic count. Nonetheless, both Morris et al.'s (1999) and Moore's (1992) data suggest that a component of the Manx Group may have been derived from recycled orogenic material.

\section{Discussion of petrographical results}

Quantitative analysis of the Manx Group samples in the form of QFL (Fig. 3) and QmFLt plots (Burnett 1999) suggest that the sediment was derived almost exclusively from a craton interior. The Glion Cam unit and Santon Formation contain the most immature sandstones and these are among the oldest samples (Tremadoc-early Arenig) (Molyneux pers. comm.).

Qualitative petrography also provides important information on the nature of the source area. The high proportion of quartz (and quartzose lithic fragments) as well as the dominance of alkali feldspar over the more chemically unstable plagioclase in the Manx Group suggests that the source was exposed to prolonged weathering and that the sediment is at least partly multicyclic. This mineralogy is consistent with derivation from granitic or acidic high-grade metamorphic rocks. However, several sedimentary cycles may have been involved before final deposition, as supported by the presence of rare rounded detrital grains. Sedimentary lithic fragments, such as quartz arenite, are obvious indicators of at least second cycle detritus. In addition, the Manx Group contains rounded grains of zircon and tourmaline with very minor amounts of rutile but no other heavy minerals. Zuffa (1985) suggested that sediments containing only these most stable heavy minerals indicate recycling of detrital material.

All Manx Group sandstone samples contain strained quartz although this could in part be due to the post-depositional effects of folding and metamorphism. However, many of the samples contain both strained and unstrained quartz suggesting that some of the strain was inherited from the source area. Young (1976) attributes many of the deformation, recovery and primary recrystallization features typical of the inherited quartz fabrics within the Manx Group to greenschist metamorphism or formation as a plutonic mineral. This is compatible with granitic and/or metamorphic sources adding weight to the interpretation that the Manx Group sediments were derived from continental basement.

The presence of sedimentary lithic fragments such as quartz arenite is indicative of the existance of sedimentary sequences in the source region. Chert fragments are likely to be polycyclic but originally derived from obducted deep-sea strata. In contrast, felsic volcanic clasts in the Manx Group may be used as evidence for contemporaneous igneous activity although these are extremely rare. However, using the petrographical criteria of Zuffa (1985) and considering their rarity, they are more likely to be derived from a minor, palaeovolcanic sequence.

Petrographical data alone suggest that the Manx Group was primarily sourced from granitic and metamorphic basement rock typical of a craton interior. Evidence for the polycyclic nature of much of the Manx Group sediment and the difficulty in producing first cycle quartz arenites indicates that additional sediment input has come from mature sedimentary sequences. A minor palaeovolcanic source is also suggested. The source region, however, may have been more heterogeneous than is indicated by the suite of lithic fragments, the less stable ones having being broken down during transport from the source or during diagenesis.

\section{Geochemistry}

Geochemical investigation of the Manx Group has been carried out by analysing 116 samples for major and trace element content of which 63 are sandstones and 53 mudstones. The results for 97 of these are reported in Burnett (1999). The data for a further 19 samples collected to fill gaps in coverage are listed in Table 2. The analyses were determined using X-ray fluorescence (XRF) spectrometry at the University of Keele following the method of Norrish \& Hutton (1969). In addition, the rare earth element (REE) concentrations of 35 of the sample group were analysed at Oxford Brookes University. $0.5 \mathrm{~g}$ of powdered sample was added to $1.5 \mathrm{~g}$ of flux $\left(\mathrm{LiBO}_{2}\right)$, fused for 30 minutes at $1000{ }^{\circ} \mathrm{C}$ and then added to a mixture of $70 \mathrm{ml}$ of $2 \mathrm{~N} \mathrm{HCl}$ and $40 \mathrm{ml}$ distilled de-ionized water. After ion exchange chromatography, REE concentrations were analysed using an inductively-coupled plasma atomic emission spectrometer (ICP-AES). Blank samples were run in conjunction with Manx Group samples to assess contamination. The precision of the method used was assessed through repeat analyses of samples and is $\pm 1.5 \%$ expressed as standard error. Further details of the REE analysis method used are given in Burnett (1999).

Major element sandstone-mudstone analysis. Bivariate plots have proved effective in defining chemostratigraphic sub-divisions of the Manx Group. Two examples are shown in Figure 4 which clearly differentiate Lonan-type sandstones from Agneash-type in terms of lower $\mathrm{SiO}_{2}$ content and higher amounts of $\mathrm{Na}_{2} \mathrm{O}$, $\mathrm{TiO}_{2}$ and $\mathrm{K}_{2} \mathrm{O}$. Lonan-type units also typically have higher concentrations of $\mathrm{Al}_{2} \mathrm{O}_{3}, \mathrm{Ni}, \mathrm{Th}, \mathrm{Nb}$ and $\mathrm{Y}$ (Burnett 1999). Mudstones are harder to discriminate but they do show the same general trends. Sandstones from Injebreck-type units show characteristics that are intermediate between Lonan-type and Agneash-type with $\mathrm{Na}_{2} \mathrm{O}$ most similar to Agneash-type and $\mathrm{SiO}_{2}, \mathrm{TiO}_{2}, \mathrm{Al}_{2} \mathrm{O}_{3}, \mathrm{Ni}$, Th and $\mathrm{Y}$ most similar to Lonantype. No simple discrimination can be made between Injebreck units that are mid-late Arenig in age and those in the NW corner of the island that have recently been dated by Molyneux (pers. comm.) as Tremadoc, although lithologically there are clear differences (Quirk \& Burnett 1999).

As the chemostratigraphic trends in the Manx Group appear to have both temporal and spatial significance (Fig. 4), the variation is thought, at least in part, to be due to differences in provenance (Burnett 1999). Roser \& Korsch (1986) have developed a bivariate tectonic discriminator which uses $\mathrm{SiO}_{2}$ contents and $\mathrm{K}_{2} \mathrm{O} / \mathrm{Na}_{2} \mathrm{O}$ ratios for both sandstones and mudstones. The fields are based on ancient sandstone-mudstone pairs, cross-checked against modern sediments from known 


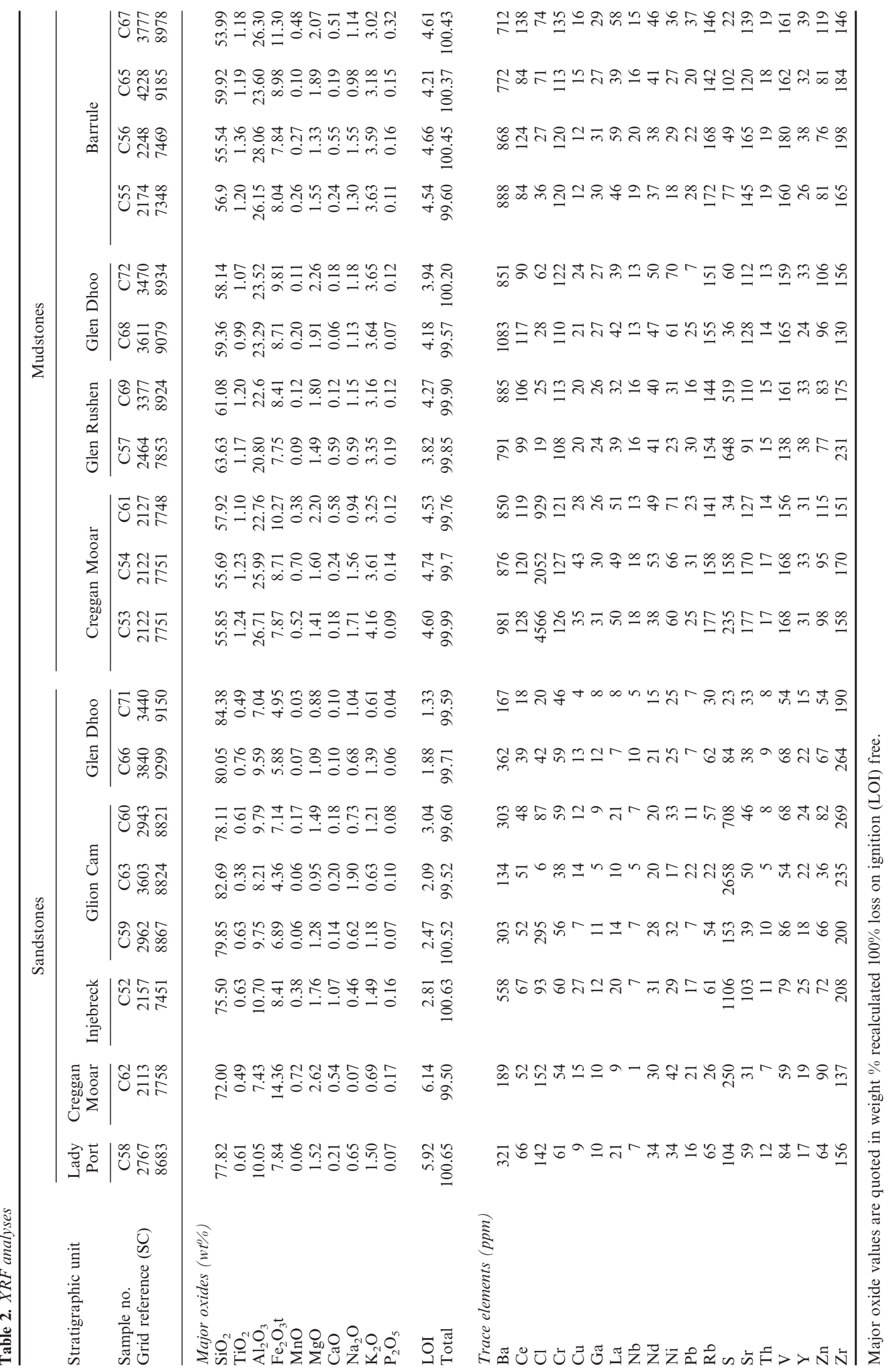



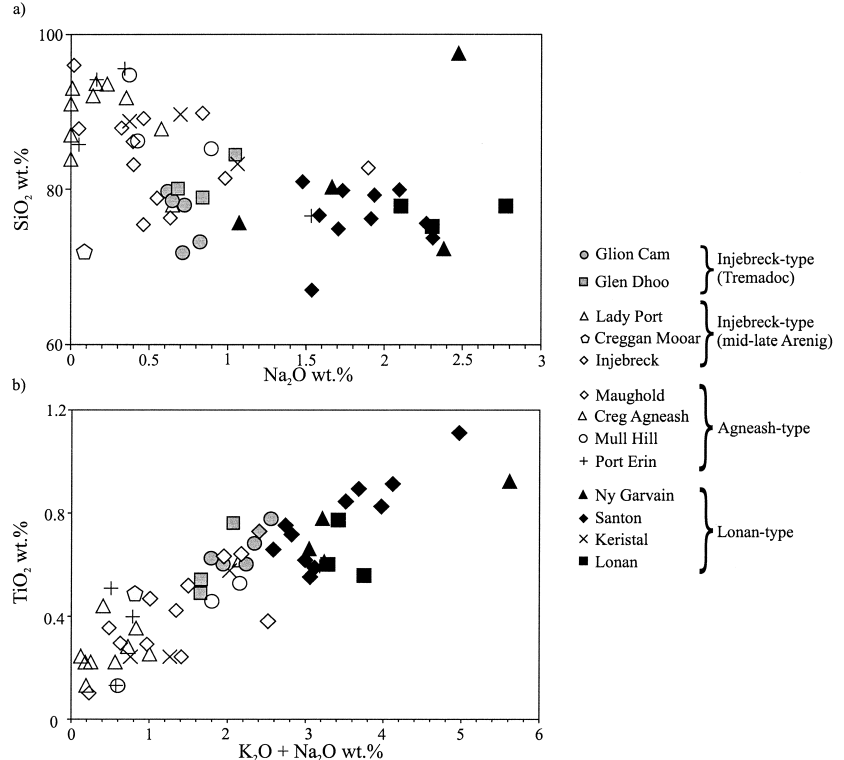

Fig. 4. Bivariate plots of (a) $\mathrm{Na}_{2} \mathrm{O}$ v. $\mathrm{SiO}_{2}$ and (b) $\mathrm{K}_{2} \mathrm{O}+\mathrm{Na}_{2} \mathrm{O}$ v. $\mathrm{TiO}_{2}$ for Manx Group samples. Lonan-type samples are shaded black, Agneash-type are unshaded and Injebreck-type are grey. The Glen Dhoo and Glion Cam unit samples are shown in a darker grey in order to reflect their uncertain relationship with the rest of the Manx Group. One Ny Garvain sample plots off the chart on Figure $3 \mathrm{a}$ with $4.3 \mathrm{wt} \% \mathrm{Na}_{2} \mathrm{O}$.

tectonic settings. The plotted positions and the trend of the tie-line between the sandstone-mudstone pairs were considered to be characteristic of specific source types. With this, Roser \& Korsch (1986) were able to differentiate between sediments derived from volcanic island arcs (ARC), active continental margins (ACM) and passive continental margins (PM). Associated with subduction zones, ARC-derived material is typical of fore-arc, back-arc and inter-arc basins formed on oceanic crust. ACM-derived material occurs in similar settings but on continental crust. PM sediments are derived from stable continental areas and deposited in intra-cratonic basins or on passive continental margins.

Using Roser \& Korsch's (1986) classification (Fig. 5), stratigraphic units in the Manx Group are PM- or ACMderived. The samples that plot clearly within the PM field are dominated by quartz-rich sandstones of Agneash-type such as the Creg Agneash and Mull Hill Formations (Fig. 5b) although, in addition, most of the more matrix-rich sandstones of Injebreck-type are also classified as PM (Fig. 5c). The Lonan, Ny Garvain, Barrule and Glen Rushen Formations are more typical of an active continental margin although the significance of the data from the Barrule and Glen Rushen Formations is questionable as no sandstones were available.

Discriminant function analysis is another method for determining the provenance of sediments using geochemical data. This is a statistical technique that defines two values (function 1 and function 2) as weighted sums of the concentrations of specific major elements that best separate samples into groups defined by the tectonic settings of the source. The discriminant functions of Roser \& Korsch (1988) use $\mathrm{Al}_{2} \mathrm{O}_{3}, \mathrm{TiO}_{2}, \mathrm{Fe}_{2} \mathrm{O}_{3} \mathrm{~T}$, $\mathrm{MgO}, \mathrm{CaO}, \mathrm{Na}_{2} \mathrm{O}$ and $\mathrm{K}_{2} \mathrm{O}$ contents as the variables and were designed to discriminate between four sedimentary provenance types. These are: mafic ( $\mathrm{P} 1$, ocean island arc source, similar to ARC-derived); intermediate ( $\mathrm{P} 2$, mature island arc, also similar to ARC-derived); felsic (P3, ACM-derived); and recycled
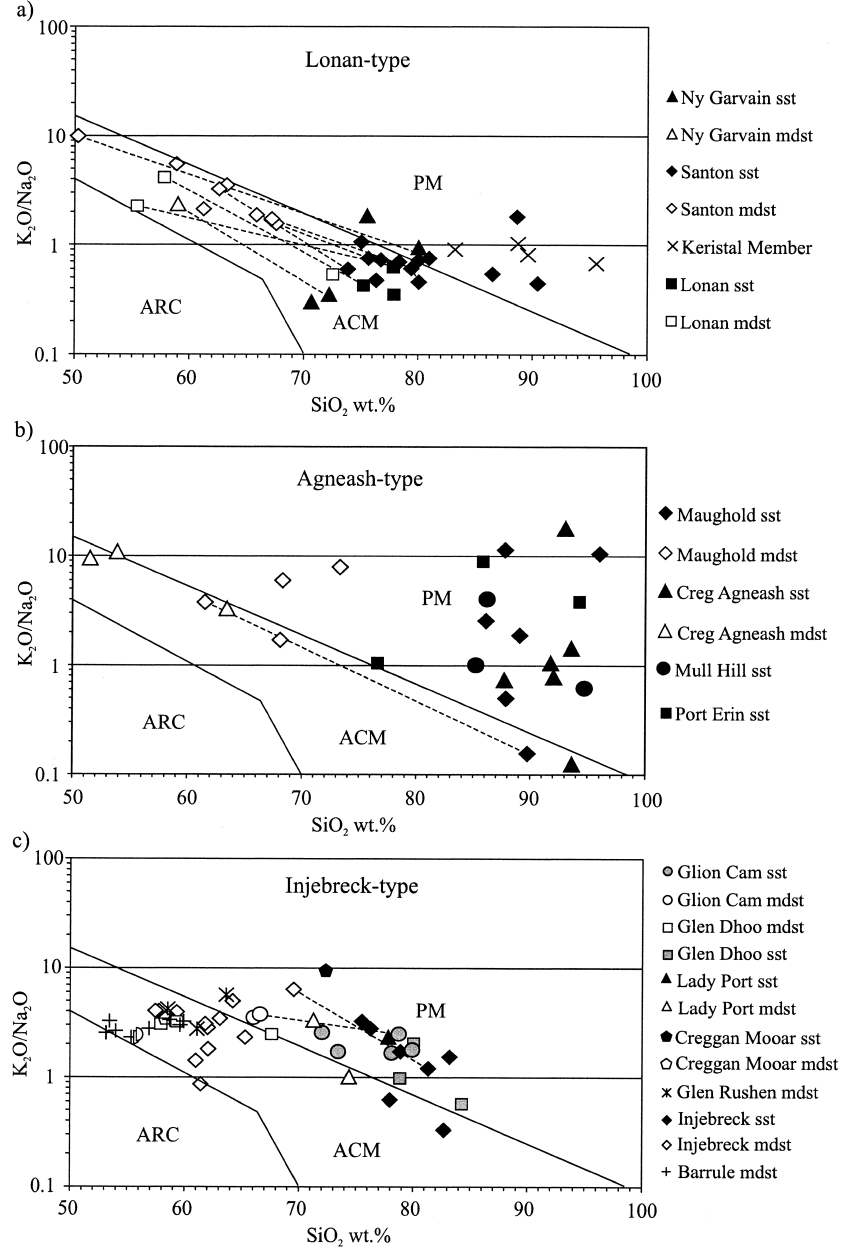

Fig. 5. Provenance discrimination diagrams of Roser \& Korsch (1986) with Manx Group sandstones (closed symbols) and mudstones (open symbols) plotted. (a) Lonan-type samples, (b) Agneash-type samples and (c) Injebreck-type samples. Dashed tie-lines between samples indicate sandstones and mudstones are taken from the same turbidite flow. ARC, volcanic island arc provenance; ACM, active continental margin; PM, passive margin.

(P4, granitic-gneissic or sedimentary source area, similar to PM-derived).

Roser \& Korsch's (1988) discriminant function analysis has been carried out on the Manx Group (Fig. 6). In cases where sandstones and mudstones from the same stratigraphic unit have been analysed, the majority of mudstones plot in a different provenance field to the sandstones. Roser \& Korsch (1988) state that where sandstones and mudstones plot in different fields, the trend of a line joining the two may resolve any ambiguity over provenance type. A P3 (felsic) source is interpreted where the mudstone has a greater function 1 and a lesser function 2 score than its respective sandstone, and a P4 (recycled) source is indicated by a mudstone with greater function 1 and 2 scores than its paired sandstone. In general, however, the sandstones are thought to provide a more reliable indication of provenance.

With rare exceptions, the majority of Manx Group sandstones plot within the P4 (recycled) field (Fig. 6), supporting the interpretation that they are derived from a craton interior or a recycled orogenic terrane. Mudstones from the Maughold Formation also plot within the P4 (recycled) field. Mudstones 

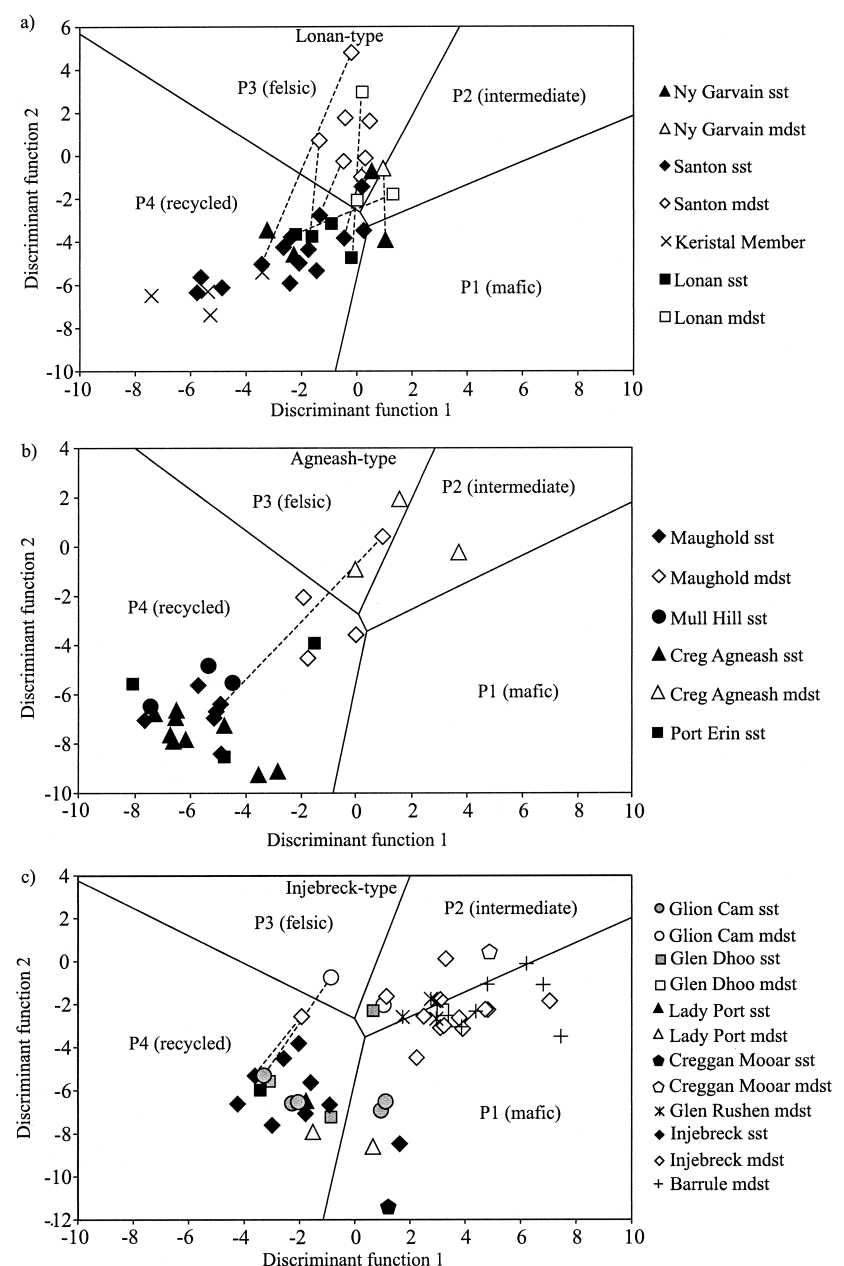

Fig. 6. Provenance discrimination diagrams of Roser \& Korsch (1988) with Manx Group sandstones (closed symbols) and mudstones (open symbols) plotted. (a) Lonan-type samples, (b) Agneash-type samples and (c) Injebreck-type samples. Dashed tie-lines between samples indicate sandstones and mudstones are taken from the same turbidite flow.

from the Creg Agneash, Injebreck, Lonan, Glen Dhoo and Santon units plot within the P2 (intermediate) and P3 (felsic) fields although, by comparison to the sandstones, these intervals are more appropriately classified as P4 (recycled).

If the results are analysed in more detail it appears that the Glion Cam unit (Tremadoc), the Ny Garvain Formation (early Arenig) and the Creggan Mooar Formation (mid-Arenig) have more immature characteristics in that they stray to the greatest extent from the P4 (recycled) field. This could indicate minor input of less mature detritus such as volcanic material.

The Barrule and Glen Rushen Formation mudstones plot in P1, P2 and P3 fields suggesting that they may have been derived in part from mafic to felsic igneous source areas. However, as they show values similar to mudstones from units containing sandstones with overall P4 associations (Fig. 6) it is perhaps more likely that they too are derived from a $\mathrm{P} 4$ (recycled) source area and plot in different fields solely as a result of their fine grain-size.

Sandstone multi-element plots. Floyd et al. (1991) compared greywacke compositions on multi-element variation diagrams normalized to upper continental crust (after Taylor
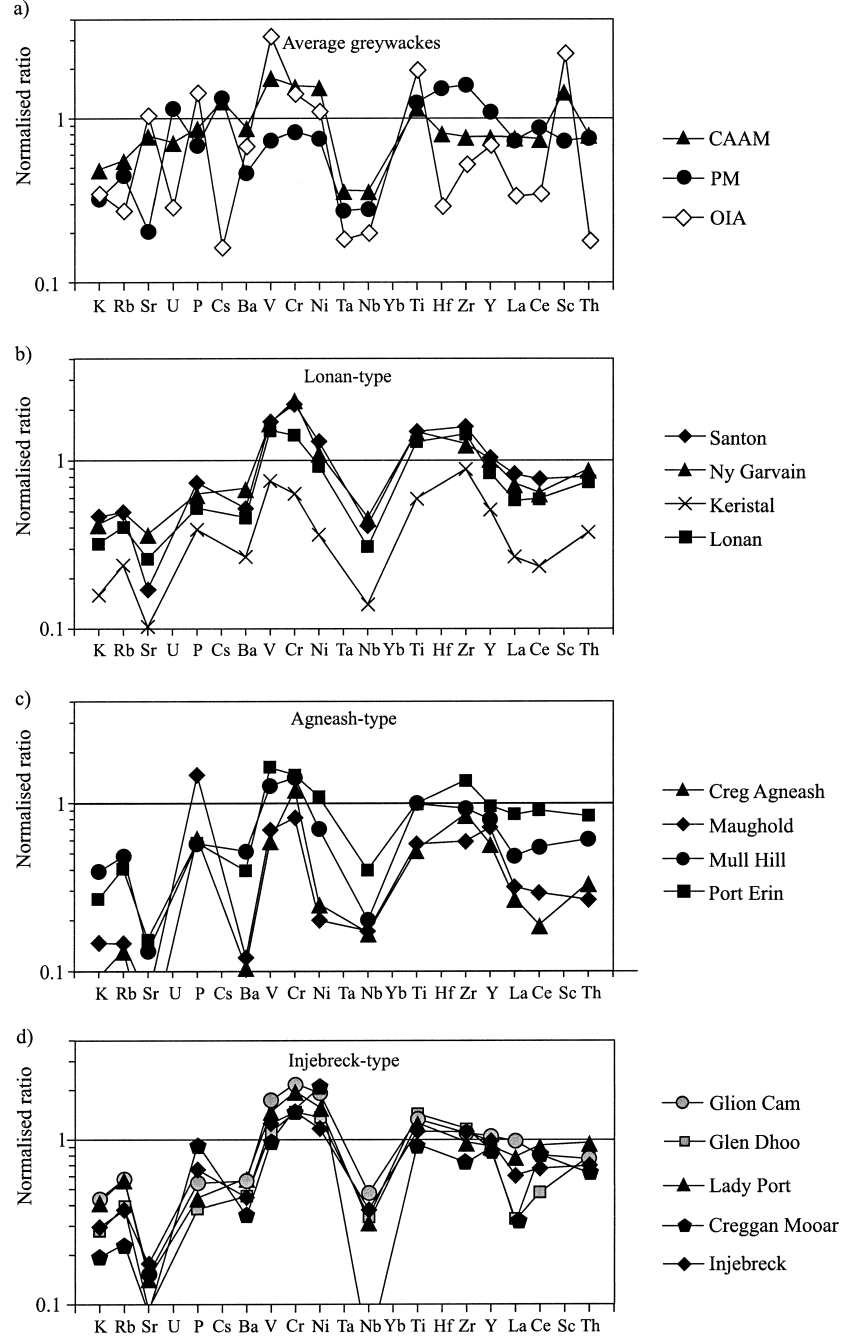

Fig. 7. Multi-element plots of (a) Floyd et al.'s (1991) average greywacke compositions from passive margin (PM), continental arc/active continental margin (CAAM) and oceanic island arc (OIA) settings normalized to upper continental crust values; (b-d) average Manx Group unit patterns. (b) Lonan-type samples, (c) Agneash-type samples and (d) Injebreck-type samples.

\& McLennan 1985) (Fig. 7a) in order to determine sediment source from differences in concentrations of elements. This technique was applied to the Manx Group and Figure 7b-d shows the resultant multi-element plots. The elements are arranged from left to right in order of decreasing ocean residence time and consist of a potentially mobile group $(\mathrm{K}-\mathrm{Ni})$ and a more immobile group (Ta-Th). For comparison, average greywackes from passive margin settings $(\mathrm{PM})$, continental arc/active continental margins (CAAM) and oceanic island arc (OIA) are shown. Floyd et al. (1991) recognized a number of source-distinguishing anomalies.

(a) $\mathrm{Nb} / \mathrm{Nb}^{*}$ ratios (actual normalized $\mathrm{Nb}$ abundance divided by predicted normalized $\mathrm{Nb}$ abundance based on straight extrapolation between $\mathrm{Ni}$ and $\mathrm{Ti}$ ). These are typically lower for source areas associated with oceanic island arcs than those associated with continental crust.

(b) Relative abundances of V, Cr, Ni, Ti and Sc. Anomalies $>1$ for all five elements tend to indicate mafic input typical of an active margin. Passive margin environments usually have anomalies of $<1$. 

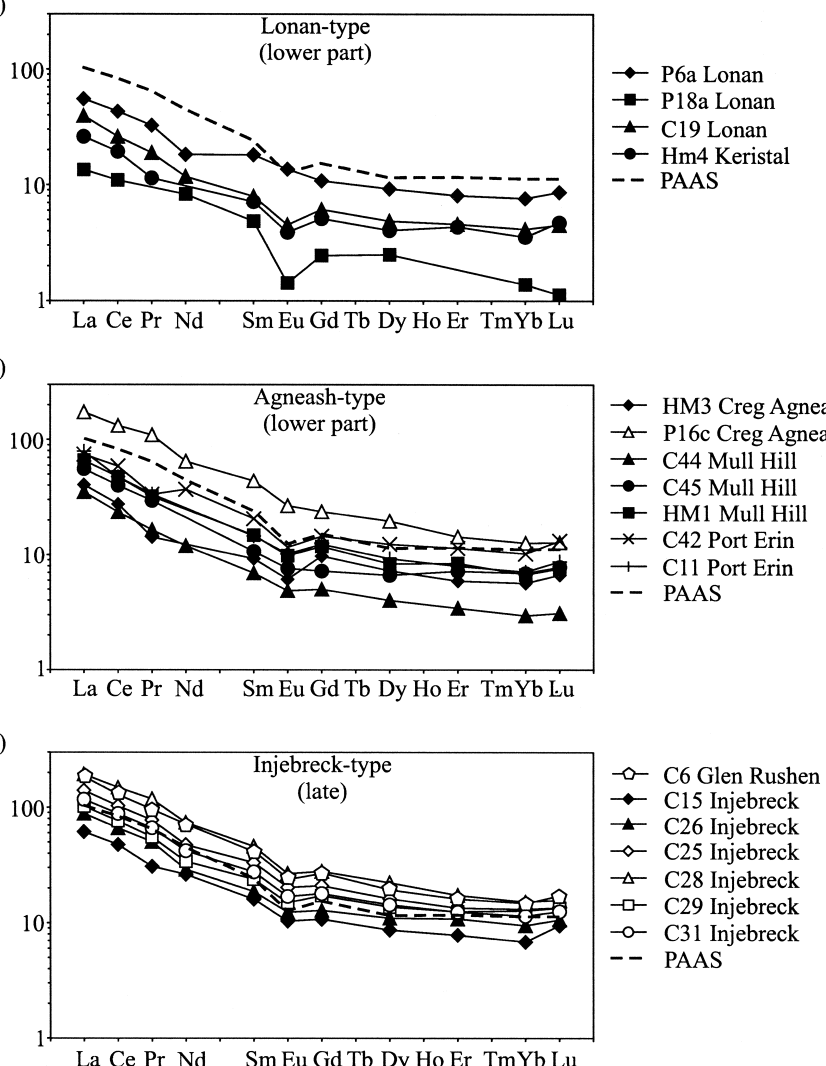

b)

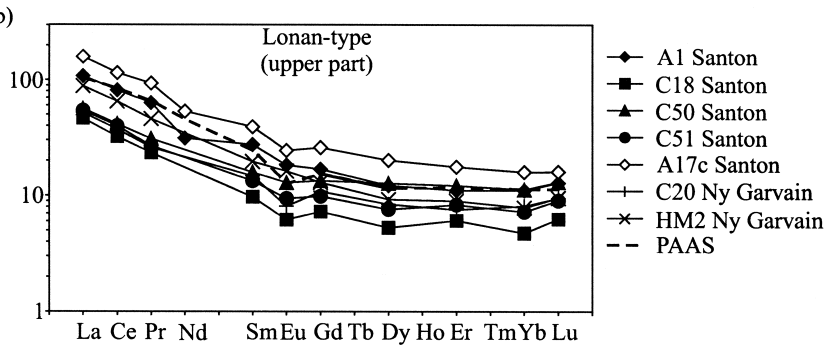

d)
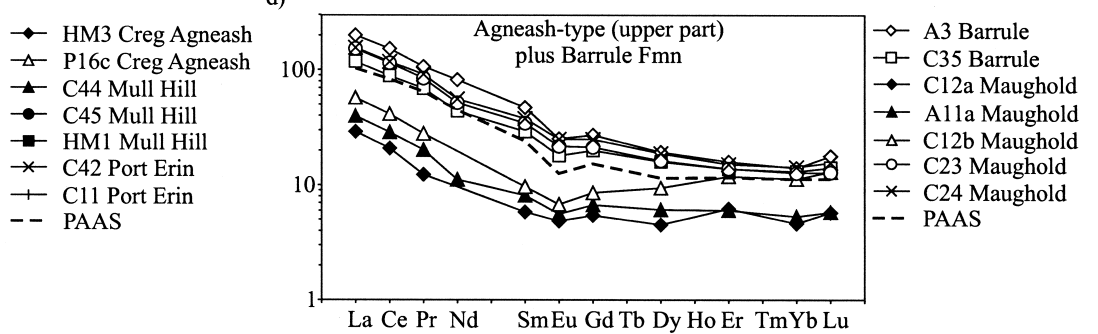

f)

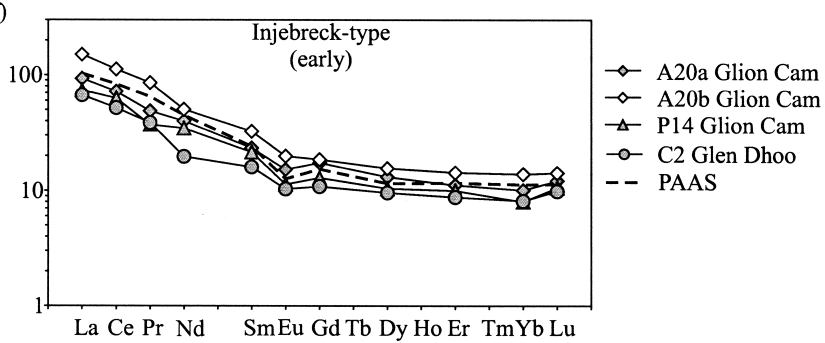

Fig. 8. Chondrite-normalized REE patterns for Manx Group samples plotted against PAAS. (a) Lonan-type samples (lower part), (b) Lonan-type samples (upper part), (c) Agneash-type samples (lower part), (d) Agneash-type (upper part) plus Barrule Formation samples, (e) Injebreck-type samples (late), (f) Injebreck-type samples (early). Closed symbols indicate sandstones, open symbols indicate sandstones.

(c) Relative abundances of $\mathrm{Hf}, \mathrm{Zr}$ and $\mathrm{Y}$. Positive anomalies correlate with the presence of heavy minerals, typical of passive margins.

(d) Relative abundance of $\mathrm{Sr}$ and $\mathrm{P}$. Peaks suggest mafic input corresponding to an active margin setting. Troughs are indicative of passive margins.

Within individual Manx Group units, different samples show similar multi-element patterns (Burnett 1999) and therefore average patterns are considered representative (Fig. 7). However, four samples were not included in the averages because of their unusual compositional trends, explained by very low element concentrations as a result of quartz dilution (Burnett 1999).

On the basis of $\mathrm{Nb} / \mathrm{Nb}^{*}$ ratios and relative abundances of $\mathrm{Ti}$ and P, the Manx Group shows characteristics of PM or CAAM settings. In general there is more evidence of PM affinity, specifically in the relative abundances of Sc, Hf, Zr, Y and $\mathrm{Sr}$ (Fig. 7). However, CAAM attributes are indicated by elevated values of $\mathrm{V}, \mathrm{Cr}$ and $\mathrm{Ni}$, particularly in the Glion Cam, Santon, Ny Garvain and Lady Port units, possibly showing that they contain minor amounts of mafic material.

Rare earth element analysis. Rare earth elements (REE) are considered to be immobile under most conditions of weathering, diagenesis and up to moderate levels of metamorphism (e.g. Cullers et al. 1974). This property has led to several studies of REE variation to determine the tectonic setting of deposition (e.g. McLennan et al. 1990).

The REE are commonly grouped according to their atomic mass into those termed light (LREE) and heavy (HREE),
$\mathrm{La}-\mathrm{Sm}$ and $\mathrm{Gd}-\mathrm{Lu}$, respectively. The abundances of eleven REE (La, Ce, Pr, Nd, Sm, Eu, Gd, Dy, Er, Yb and Lu) were determined for 36 samples from the Manx Group. The results of this analysis are shown in Figure 8 for each stratigraphic unit from which the samples were collected. They are normalized to chondrite abundance and plotted along with PostArchaean Average Australian Shale (PAAS) to aid comparison. Eu anomalies are expressed as $\mathrm{Eu} / \mathrm{Eu}^{*}$ values using the method of McLennan et al. (1990):

$$
\mathrm{Eu} / \mathrm{Eu}^{*}=\mathrm{Eu}_{\mathrm{N}} / \sqrt{ }\left[\left(\mathrm{Sm}_{\mathrm{N}}\right)\left(\mathrm{Gd}_{\mathrm{N}}\right)\right]
$$

where $\mathrm{Eu}^{*}$ represents the expected $\mathrm{Eu}$ abundance for a smooth chondrite-normalized $\left({ }_{N}\right)$ REE pattern.

In general, the Manx Group shows similar chondritenormalized REE abundance patterns to PAAS although the mudstone samples are all enriched relative to PAAS while the sandstones are depleted due to quartz dilution. All the samples are LREE enriched relative to HREE with flat HREE patterns and, apart from two samples mentioned below, display negative $\mathrm{Eu}$ anomalies $\left(\mathrm{Eu} / \mathrm{Eu}^{*}\right.$ values $\left.<1\right)$. This suggests that the Manx Group is composed of sediment derived from old upper continental crust and/or young differentiated arc material. According to McLennan et al. (1990) these provenance components may be found in several basin types, but rarely in a fore-arc setting. Based on other geochemical and petrographical data discussed herein, it is considered unlikely that the Manx Group was derived from young differentiated arc material and therefore old upper continental crust is the most likely source.

The two samples with slightly positive Eu anomalies are P6a and HM2, from the Lonan and Ny Garvain Formations, 
respectively. This may reflect that there has been some influx of material from a juvenile island arc. However, as the Lonan Formation also provides a sample with the second largest negative $\mathrm{Eu}$ anomaly (P18a on Fig. 8a), this indicates the potential for variation within a single stratigraphic unit. The positive Eu anomalies are therefore more likely to be the result of minor and sporadic input of detritus from an eroded palaeovolcanic sequence. Overall REE concentrations and $\mathrm{Eu} / \mathrm{Eu}^{*}$ ratios in the Manx Group are broadly consistent with sediment deposited on a passive margin.

Geochemical summary. Assuming that the provenance indicators used here accurately discriminate between passive margin and active continental margin sediments, the overall indication is that the Manx Group was deposited on a passive margin. However, the Lonan and Ny Garvain Formations (early Arenig) and, to a degree the Glion Cam (Tremadoc), Santon (early Arenig) and Lady Port (late Arenig) units, show evidence of limited input from material more typical of an active margin.

\section{Summary of provenance indicators}

Petrographical study reveals that the Manx Group is dominated by quartzose detritus. Although present in only low concentrations, feldspar is mostly alkaline in composition and lithic fragments are primarily of polycrystalline quartz (granite, quartz schist, chert and quartz arenite). Volcanic lithic fragments are rare but of acidic composition and appear to be palaeovolcanic rather than juvenile. Rounded grains have occasionally been observed in thin section which, together with the very mature suite of heavy minerals present, indicates that at least some of the Manx Group detritus is polycyclic. This evidence is consistent with the erosion of mature sedimentary sequences with a minor palaeovolcanic component and the breakdown of granites and acidic gneisses typical of continental basement. The Glion Cam unit (Tremadoc) and Santon Formation (early Arenig) are the most immature units but still show similar provenance characteristics to the rest of the Manx Group.

Geochemical data are broadly consistent with the petrographical interpretation although the provenance signal is more mixed. The dominance of $\mathrm{SiO}_{2}$, generally low $\mathrm{Fe}_{2} \mathrm{O}_{3} \mathrm{~T}$ and $\mathrm{MgO}$ concentrations and REE patterns with negative Eu anomalies suggest that the Manx Group is dominated by mature, cratonic detritus deposited on a passive margin. However, although the evidence is limited, some provenance indicators such as the multi-element plots of Floyd et al. (1991), and two samples that lack a Eu anomaly, indicate that a minor amount of continental arc or active continental margin volcanic material may also have been supplied to the basin. This is true of the oldest units (Glion Cam, Lonan, Ny Garvain and Santon) which are Tremadoc-early Arenig in age and in the youngest formation (Lady Port) which is late Arenig.

\section{Tectonic setting of the Manx Group}

The majority of the Manx Group comprises mature cratonic detritus typical of a passive margin. However, a minor igneous component has been identified and it is important to know whether this was derived from a contemporaneous source or from palaeovolcanic rocks. Stone \& Evans (1997) analysed three samples from the Manx Group for $\varepsilon \mathrm{Nd}$ isotope values. Two samples from the Santon Formation showed no juvenile input (values of -6.0 and -5.1 ) but a third sample from the Mull Hill Formation was positive $(+2.1)$, possibly indicating input from coeval mantle-derived volcanism. However, Stone et al. (1999) suggested this result be treated as provisional as it was obtained in the vicinity of a felsic dyke. The otherwise mature characteristics of the Mull Hill Formation also cast doubt on the validity of the analysis.

Within the several thousand metres of succession that make up the Manx Group, only two intervals of volcanic rocks have been identified; no more than a few tens of metres thick and mostly consisting of highly altered tuffs. One of these intervals, known as the Peel volcanics, has been dated as early Arenig, similar to the Santon Formation, on the basis of acritarchs (Molyneux 1999). The other volcanic interval at Ballaquane has not been dated and there is a possibility that it is not part of the Manx Group succession. Both these volcanics are exposed close to a major fault which separates the Manx Group from Silurian strata (Morris et al. 1999) and their significance remains questionable.

There are a number of tectonic hypotheses that could explain the presence of a detrital component of volcanic origin within what are otherwise mature sediments.

(1) Deposition in a fore-arc basin of a continental island arc or active continental margin where volcanic material was trapped locally so as not to reach the main part of the basin while rivers carrying mature sediment from the craton interior largely bypassed the arc. A potential problem with this model is that airborne volcanic material should still have been distributed regionally.

(2) Deposition on the continental side of a back-arc basin, the majority of the detritus being derived from the continent (Quirk \& Kimbell 1997). Volcanic activity within the back-arc basin itself or a minor component from the island arc may have provided some juvenile detritus. However, the general absence of airborne volcanic material in the Manx Group is again difficult to explain.

(3) Deposition during transition from a passive margin to a fore-arc basin setting. This would allow the continued deposition of mature detritus from the craton interior or from local continental crust, as well as sporadic but gradually increasing influxes of juvenile volcanic material. The difficulty in recognizing such transitional situations has been noted by Mack (1984). However, the Manx Group appears to show an overall decrease in volcanic influence upwards in the succession, the opposite trend to that expected during such a transition.

(4) Deposition on a passive margin (e.g. Quirk \& Burnett 1999). Such a setting would allow large quantities of mature sediment from the continental interior to reach the depositional basin. In addition, limited amounts of non-coeval igneous detritus may have been supplied from a dissected late Precambrian volcanic centre (Thorpe 1979).

The majority of the Manx Group has petrographical and geochemical characteristics indicative of passive margin conditions and therefore hypothesis 4 is favoured. The source of the minor volcanic detritus has not been positively identified. Van Staal et al. (1998) speculate that the Penobscot oceanic island arc extended from the Appalachian to the Avalonian sector of the Iapetus during the Cambrian and was obducted onto the Avalonian margin during the Tremadoc. Although this would potentially account for the presence of volcanic material in the Manx Group basin, it is difficult to reconcile 
this with the strong passive margin signal in geochemical data and general lack of volcanic detritus observed in thin section. The presence of small amounts of typically silicic volcanogenic material is more easily explained by the erosion of the late Precambrian continental arc identified on the northern margin of Gondwana by Thorpe (1979).

Although the distance the turbidites of the Manx Group have travelled remains unconstrained, the interpretation that the sediment was deposited on a passive margin has implications for when Eastern Avalonia rifted from Gondwana. The supply of detritus from a continental interior with little incorporation of volcanic material into the basin suggests that Eastern Avalonia remained attached to Gondwana throughout deposition of the Manx Group. This indicates that rifting occurred no earlier than latest Arenig and therefore probably in the Llanvirn, an interpretation consistent with patterns of provinciality in benthic fauna (Cocks 2000).

In summary, the depositional setting of the Manx Group is envisaged to be a passive margin receiving detritus from continental basement and quartzose sediments. A minor volcanic component in the Glion Cam, Lonan, Santon, Ny Garvain and Lady Port units is thought to have been derived from erosion of an ancient active continental margin incorporated within Gondwana but, without further $\varepsilon \mathrm{Nd}$ data, the existence of contemporaneous volcanic activity cannot entirely be discounted.

\section{Manx Group regional correlatives}

The Skiddaw Group is approximately the same age as the Manx Group (Molyneux 1999) and it too is interpreted to have been deposited on a passive margin fed by a recycled orogenic terrane (Cooper et al. 1995). Although a similar tectonic setting is envisaged, the source of the Manx Group appears to be more mature than that of the Skiddaw Group (Moore 1992; Burnett 1999) probably because the two basins were receiving detritus from different river systems. The Ribband Group of SE Ireland can also be correlated with the Manx Group and several gross similarities are identifiable in their respective stratigraphies (McConnell et al. 1999). The Ingleton Group of northwest England is thought to be contemporaneous with the Manx and Skiddaw Groups (Stone et al. 1999). Petrographical and geochemical work by Moore (1992) suggests that it contains a significant volcanogenic component. In addition, marked differences also occur in $\varepsilon \mathrm{Nd}$ values between the Skiddaw and Ingleton Groups (Stone \& Evans 1997; Miller \& O'Nions 1984). The implication is that the Ingleton Group is unlikely to directly correlate with either the Manx or Skiddaw Group sequences.

Hughes \& Kokelaar (1993) report that the oldest volcanogenic strata in the Skiddaw Group is of early Llanvirn age, much younger than in the Manx Group. However, the Ribband Group does contain volcanics interpreted to be of an early Arenig age. These consist of a thickness of at least $180 \mathrm{~m}$ of basalt and dolerite thought to be subduction related (McConnell \& Morris 1997). The implication is that there was significant variation in the nature and timing of volcanism along the northern margin of Eastern Avalonia.

Another difficulty exists in relating the tectonic evolution of Wales with that of other parts of the northern margin of Eastern Avalonian. The late Tremadoc Rhobell Volcanic Complex records the onset of ensialic arc volcanism in Wales, considered to mark the beginning of subduction of Iapetus oceanic crust beneath the Avalonian margin (Kokelaar 1979).
This volcanism ceased in early Arenig times and was replaced by tholeiitic volcanism, interpreted by Fitton et al. (1982) to have developed on thinned continental crust behind an arc stretching from Leinster to the Lake District. It is therefore difficult to reconcile the apparent passive margin setting of the Manx and Skiddaw Groups with contemporaneous arc-related tectonics in Wales. One possible answer is that the Welsh volcanics have been displaced a considerable distance laterally along large strike-slip faults during the oblique convergence of Eastern Avalonia against Laurentia (Kokelaar 1988). Such a model might also explain important differences in the lithofacies and volcanic content of the Manx, Skiddaw and Ribband Groups (Quirk \& Burnett 1999). The difficulty in assessing the importance of fault-bounded terranes should not be underestimated when trying to constrain models for the evolution of Eastern Avalonia.

\section{Conclusions}

The provenance of the Manx Group has been assessed using integrated petrographical and geochemical studies, the results of which are largely in agreement. This approach has revealed the dominance of mature, quartzose sandstones within the Manx Group, probably derived from a craton interior. A minor input of igneous detritus has been detected in the Glion Cam unit (Tremadoc), Ny Garvain, Lonan and Santon Formations (early Arenig) and Lady Port Formation (late Arenig). The petrographical and geochemical data provide little evidence for the existence of a contemporaneous volcanic arc and the igneous material is interpreted instead to have been derived from a palaeovolcanic source.

The provenance characteristics suggest that the Manx Group was deposited on a passive margin which received large amounts of mature detritus from the interior of Gondwana in addition to minor volcanic material from a deeply dissected late Precambrian continental margin arc.

The main implication of this work is that Eastern Avalonia remained attached to Gondwana during the Tremadoc and Arenig and that Iapetus oceanic crust did not subduct beneath the region until later, probably during the Llanvirn. This appears to contradict evidence from other areas, particularly Wales where subduction-related volcanism occurs in the late Tremadoc. Many of the difficulties in understanding the relationship between these different areas may be due to the separate terranes being juxtaposed along large strike-slip faults during the Caledonian orogeny.

We would like to thank D.S. Stow, H.A. Armstrong and J. Wood for helpful comments and suggestions in reviewing this paper. In addition, the authors are grateful to Nigel Woodcock, Rob Barnes, Greg Power, John Morris, Mike Fowler, Gilbert Kelling and Rob Strachan for valuable assistance and discussion. D.J.B. acknowledges the receipt of a grant from the Isle of Man Government Department of Education and financial assistance from the Manx Heritage Foundation, the Isle of Man Department of Tourism and Leisure and Oxford Brookes University.

\section{References}

Barnes, R.P. \& Stone, P. 1999. Trans-Iapetus contrasts in the geological development of southern Scotland (Laurentia) and the Lakesman Terrane (Avalonia). In: Woodcock, N.H., Quirk, D.G., Fitches, W.R. \& BARNeS, R.P. (eds) In sight of the suture: the Palaeozoic geology of the Isle of Man in its Iapetus Ocean context. Geological Society, London, Special Publications, 160, 307-327. 
Barnes, R.P., Power, G.M. \& CoOPER, D.C. 1999. The definition of sandstonebearing formations in the Isle of Man and correlations with adjacent areas - evidence from sandstone geochemistry. In: Woodcock, N.H., Quirk, D.G., Fitches, W.R. \& BARNes, R.P. (eds) In sight of the suture: the Palaeozoic geology of the Isle of Man in its Iapetus Ocean context. Geological Society, London, Special Publications, 160, 139-154.

BuRnetT, D.J. 1999. The stratigraphy, geochemistry and provenance of the Lower Palaeozoic Manx Group, Isle of Man. PhD Thesis, Oxford Brookes University

Cocks, L.R.M. 2000. The Early Palaeozoic geography of Europe. Journal of the Geological Society, London, 157, 1-10.

Cooper, A.H., Rushton, A.W.A., Molyneux, S.G., Hughes, R.A., Moore, R.M. \& Weвв, B.C. 1995. The stratigraphy, correlation, provenance and palaeogeography of the Skiddaw Group (Ordovician) in the English Lake District. Geological Magazine, 132, 185-211.

Cullers, R.L., Yek, L-I., Chaudhuri, S. \& Guidott, C.V. 1974. Rare earth elements in Silurian pelitic schists from NW Maine. Geochimica et Cosmochimica Acta, 38, 389-400.

Dickinson, W.R. 1970. Interpreting detrital modes of graywacke and arkose. Journal of Sedimentary Petrology, 40, 695-707.

DiCKINSON, W.R. 1985. Interpreting provenance relations from detrital modes of sandstones. In: Zuffa, G.G. (ed.) Provenance of Arenites. Reidel Publishing Company, Dordrecht, 333-361.

Dickinson, W.R. \& SuczeK, C.A. 1979. Plate tectonics and sandstone compositions. The American Association of Petroleum Geologists Bulletin, 63, $2164-2182$.

Dickinson, W.R., Beard, L.S., Brakenridge, G.R., Erjavek, J.L., Ferguson, R.C., Inman, K.F., Knepr, R.A., Lindberg, F.A. \& Ryberg, P.T. 1983. Provenance of North American Phanerozoic sandstones in relation to tectonic setting. Geological Society of America Bulletin, 94, 222-235.

Fitton, J.G., Thirwall, M.F. \& Hughes, D.J. 1982. Volcanism in the Caledonian orogenic belt of Britain. In: Thorpe, R.S. (ed.) Andesites. John Wiley and Sons, Chichester, 611-636.

Floyd, P.A., Shail, R., Leveridge, B. \& Franke, W. 1991. Geochemistry and provenance of Rhenohercynian synorogenic sandstones: implications for tectonic environment discrimination. In: MorTon, A.C., TodD, S.P. \& Haughton, P.D.W. (eds). Developments in Sedimentary Provenance Studies. Geological Society, London, Special Publications, 57, 173-188.

Hughes, R.A. \& Kokelaar, P. 1993. The timing of Ordovician magmatism in the English Lake District and Cross Fell inliers. Geological Magazine, 130 369-377.

Ingersoll, R.V., Bullard, T.F., Ford, R.L., Grimm, J.P., Pickle, J.D. \& SARES, S.W. 1984. The effect of grain size on detrital modes: a test of the Gazzi-Dickinson point-counting method. Journal of Sedimentology, 54, $103-116$.

KokelaAR, P. 1979. Tremadoc to Llanvirn volcanism on the southeast side of the Harlech Dome (Rhobell Fawr), N. Wales. In: Harris, A.L., Holland, C.H. \& LEAKE, B.E. (eds) The Caledonides of the British Isles - reviewed. Geological Society, London, Special Publications, 8, 591-596.

KokelaAR, P. 1988. Tectonic controls of Ordovician arc and marginal basin volcanism in Wales. Journal of the Geological Society, London, 145, 759-775.

MACK, G.H. 1984. Exceptions to the relationship between plate tectonics and sandstone composition. Journal of Sedimentary Petrology, 54, 212-220.

McConnell, B.J. \& Morris, J.H. 1997. Initiation of Iapetus subduction under Irish Avalonia. Geological Magazine, 134, 213-218.

McConnell, B.J., Morris, J.H. \& Kennan, P.S. 1999. A comparison of the Ribband Group (southeastern Ireland) to the Manx Group (Isle of Man) and Skiddaw Group (northwestern England). In : Woodcock, N.H., Quirk, D.G., Fitches, W.R. \& BARNes, R.P. (eds) In sight of the suture: the Palaeozoic geology of the Isle of Man in its Iapetus Ocean context. Geological Society, London, Special Publications, 160, 337-343.

McLennan, S.M., Taylor, S.R., McCulloch, M.T. \& Maynard, J.B. 1990. Geochemical and Nd-Sr isotopic composition of deep-turbidites: crustal evolution and plate tectonic associations. Geochimica et Cosmochimica Acta, 54, 2015-2050

Miller, R.G. \& O'Nions, R.K. 1984. The provenance and crustal residence ages of British sediments in relation to palaeogeographic reconstructions. Earth and Planetary Science Letters, 68, 459-470.

Molyneux, S.G. 1999. reassessment of Manx Group acritarchs, Isle of Man. In: Woodcock, N.H., Quirk, D.G., Fitches, W.R. \& Barnes, R.P. (eds) In sight of the suture: the Palaeozoic geology of the Isle of Man in its Iapetus Ocean context. Geological Society, London, Special Publications, 160 $23-32$.

Moore, R.M. 1992. The Skiddaw Group of Cumbria: early Ordovician turbidite sedimentation and provenance on an evolving microcontinental margin. $\mathrm{PhD}$ Thesis, University of Leeds.

Morris, J.H., Woodcock, N.H. \& Howe, M.P.A. 1999. The Silurian succession of the Isle of Man: the Late Wenlock Niarbyl Formation, Dalby Group. In:
Woodcock, N.H., Quirk, D.G., Fitches, W.R. \& BARnes, R.P. (eds) In sight of the suture: the Palaeozoic geology of the Isle of Man in its Iapetus Ocean context. Geological Society, London, Special Publications, 160, 189-211.

NANCE, R.D. \& Murphy, J.B. 1994. Contrasting basement isotopic signatures and the palinspastic restoration of peripheral orogens: example from the Neoproterozoic Avalonian-Cadomian belt. Geology, 22, 617-620.

NorRish, K. \& HutTon, J.T. 1969. An accurate x-ray spectrographic method for the analysis of a wide range of geological samples. Geochimica et Cosmochimica Acta, 33, 431-454.

Prigmore, J.K., Butler, A.J. \& Woodcock, N.H. 1997. Rifting during separation of Eastern Avalonia from Gondwana: evidence from subsidence analysis. Geology, 25, 203-206.

Quirk, D.G. \& KimbeLL, S.G. 1997. Structural evolution of the Isle of Man and central part of the Irish Sea. In: Meadows, N.S., Trueblood, S.P., Hardman, M. \& Cowan, G. (eds) Petroleum geology of the Irish Sea and surrounding areas. Geological Society, London, Special Publications, 124, $135-159$.

Quirk, D.G. \& BurnetT, D.J. 1999. Lithofacies of Lower Palaeozoic deep marine sediments in the Isle of Man: a new map and stratigraphic model of the Manx Group. In: Woodcock, N.H., Quirk, D.G., Fitches, W.R. \& BARNES, R.P. (eds) In sight of the suture: the Palaeozoic geology of the Isle of Man in its Iapetus Ocean context. Geological Society, London, Special Publications, 160, 69-88.

Quirk, D.G., Burnett, D.J., Kimbell, G.S., Murphy, C. \& Varley, J.S. 1999. Shallow geophysical and geological evidence for a regional-scale fault duplex in the Lower Palaeozoic of the Isle of Man. In: Woodcock, N.H., Quirk, D.G., FITCHES, W.R. \& BARNES, R.P. (eds) In sight of the suture: the Palaeozoic geology of the Isle of Man in its Iapetus Ocean context. Geological Society, London, Special Publications, 160, 239-257.

Roser, B.P. \& KonsCH, R.J. 1986. Determination of tectonic setting of sandstone-mudstone suites using $\mathrm{SiO}_{2}$ content and $\mathrm{K}_{2} \mathrm{O} / \mathrm{Na}_{2} \mathrm{O}$ ratio. Journal of Geology, 94, 635-650.

Roser, B.P. \& KORSCH, R.J. 1988. Provenance signatures of sandstonemudstone suites determined using discriminant function analysis of major-element data. Chemical Geology, 67, 119-139.

Simpson, A. 1963. The stratigraphy and tectonics of the Manx Slate Series, Isle of Man. Quarterly Journal of the Geological Society of London, 119, 367-400.

Stone, P. \& Evans, J.A. 1997. A comparison of the Skiddaw and Manx Groups (English Lake District and Isle of Man) using Neodymium isotopes. Proceedings of the Yorkshire Geological Society, 51, 343-347.

Stone, P., Cooper, A. \& Evans, J.A. 1999. The Skiddaw Group (English Lake District) reviewed: early Palaeozoic sedimentation and tectonism at the northern margin of Avalonia. In: WoODCock, N.H., QuiRK, D.G., Fitches, W.R. \& Barnes, R.P. (eds) In sight of the suture: the Palaeozoic geology of the Isle of Man in its Iapetus Ocean context. Geological Society, London, Special Publications, 160, 325-336.

Taylor, S.R. \& MCLennan, S. 1985. The Continental Crust: its Composition and Evolution. Blackwell, Oxford.

Thorpe, R.S. 1979. Late Precambrian igneous activity in Southern Britain. In: Harris, A.L., Holland, C.H. \& Leake, B.E. (eds) The Caledonides of the British Isles - reviewed. Geological Society, London, Special Publications, 8 , 579-584.

Van Staal, C.R., Dewey, J.F., Mac Niocaill, C. \& McKerrow, W.S. 1998. The Cambrian-Silurian tectonic evolution of the northern Appalachians and British Caledonides: history of a complex, west and southwest Pacifictype segment of Iapetus. In: BLUNDELL, D.J. \& SCOTT, A.C. (eds) Lyell: the Past is the Key to the Present. Geological Society, London, Special Publications, 143, 199-242.

Woodcock, N.H., Quirk, D.G., Fitches, W.R. \& BARNES, R.P. 1999a. In sight of the suture: the early Palaeozoic geological history of the Isle of Man. In: Woodcock, N.H., Quirk, D.G., Fitches, W.R. \& Barnes, R.P. (eds) In sight of the suture: the Palaeozoic geology of the Isle of Man in its Iapetus Ocean context. Geological Society, London, Special Publications, 160, $1-10$.

Woodcock, N.H., Morris, J.H., Quirk, D.G., Barnes, R.P., Burnett, D.J., Fitches, W.R. Kennan, P.S \& Power, G.M 1999b. Revised lithostratigraphy of the Manx Group, Isle of Man. In: Woodcock, N.H., Quirk, D.G., Fitches, W.R. \& BARnes, R.P. (eds) In sight of the suture: the Palaeozoic geology of the Isle of Man in its Iapetus Ocean context. Geological Society, London, Special Publications, 160, 4568.

Young, S.W. 1976. Petrographic textures of detrital polycrystalline quartz as an aid to interpreting crystalline source rocks. Journal of Sedimentary Petrology, 46, 595-603.

ZuFFA, G.G. 1985. Optical analyses of arenites: influence of methodology on compositional results. In: Zuffa, G.G. (ed.) Provenance of Arenites. Reidel Publishing Company, Dordrecht, 165-189. 